DOI: 10.52362/jmijayakarta.v1i2.444

\title{
PENGARUH PENGEMBANGAN APLIKASI PEMETAAN VISUAL DAN PENCATATAN PELANGGAN TERHADAP PRODUKTIVITAS PENAGIHAN PADA PT.TELEKOMUNIKASI INDONESIA
}

\author{
Eny Rifani ${ }^{*}$, Rumadi Hartawan ${ }^{2}$, Rachmawaty Haroen ${ }^{3}$ \\ Program Studi Sistem Informasi ${ }^{1}$, Program Studi Teknik Informatika ${ }^{2}$, Program Studi Sistem Informasi ${ }^{3}$ \\ Sekolah Tinggi Manajemen Informatika dan Komputer Jayakarta ${ }^{1,2,3}$ \\ 18568001@stmik.jayakarta.ac.id, rumadi@gmail.com, rachmawatyharoen@gmail.com
}

\begin{abstract}
Abstrak
Penulisan karya tulis ini bertujuan untuk memaparkan aplikasi pemetaan visual sebagai alternatif untuk menekan produktivitas penagihan di PT.Telekomunikasi Indonesia. Adapun yang menjadi latar belakang penulisan ini berusaha menemukan solusi kendala alamat tidak ditemukan yang terjadi dilapangan. Hal ini disebabkan semakin bertambahnya pelanggan yang menggunakan internet di wilayah khususnya Jakarta, pada kasus ini banyak pula pelanggan yang belum paham mengenai tata cara pembayaran, jatuh tempo tagihan dan pemutusan internet, maka terjadi banyaknya tunggakan sehingga menjadi tugas CTB (Caring Teritory Base) sebagai pihak penagihan,lalu menjadi masalah apabila alamat pelanggan tersebut tidak lengkap,tidak ada keterangan rt dan rw, nama tower,maupun lantai gedung. Akan menjadi perhatian perusahaan untuk mengurangi Revenue Loss akibat tagihan belum dibayarkan, juga tidak tercapainya target yang di tetapkan manajemen kepada karyawan. Adapun metode analisis yang digunakan penulis yaitu Object Oriented Analisis. (OOA). OOA melihat masalah berdasarkan objek pengguna sistem.Dengan OOA dapat dibuat pemodelan sistem yang sedang berjalan. Penerapan dari $O O A$ dalam penelitian ini menggunakan diagram Unified Modelling Language (UML). Diagram Unified Modelling Language (UML) yang penulis gunakan adalah rancangan Use Case Diagram rancangan Activity Diagram ,rancangan Sequence Diagram,dan rancangan Class Diagram. Metode pengembangan aplikasi atau Software Development Life Cycle (SDLC) yang penulis terapkan adalah metode waterfall.Metode waterfall memiliki ciri khusus yaitu seluruh proses pengembangan dilakukan secara berurutan yang di mulai dari tahap perencanaan konsep, pemodelan, development, pengujian dan pemeliharaan sistem. Analisa ini menemukan bahwa adanya aplikasi Find\&Go dapat membantu dalam mengatasi masalah tunggakan yang terjadi di perusahaan.
\end{abstract}

Kata kunci: Caring Teritory Base, Internet, Penagihan, Analisis

Abstract: The writing of this paper aims to present visual mapping applications as an alternative to reduce billing productivity in PT. Indonesian Telecommunications. As for the background of this writing trying to find solutions to address constraints are not found that occur in the field. This is due to the increasing number of customers who use the internet in the region, especially Jakarta, in this case many customers who do not understand about the procedures of payment, due bills and internet disconnection, then there is a lot of arrears so that it becomes the duty of CTB (Caring Teritory Base) as the billing party, then it becomes a problem if the

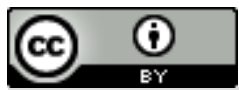

Ciptaan disebarluaskan di bawah Lisensi Creative Commons Atribusi 4.0 Internasional.

http://journal.stmikjayakarta.ac.id/index.php/IMIJayakarta 
Jurnal Manajemen Informatika Jayakarta

Volume 1, Nomor 2, April 2021, halaman 73-95
P-ISSN: 2746-5985

e-ISSN: $2797-0930$

DOI: 10.52362/jmijayakarta.v1i2.444

customer's address is incomplete, there is no information rt and $r w$, the name of the tower, as well as the floor of the building. It will be a concern for the company to reduce Revenue Loss due to unpaid bills, as well as not achieving the targets set by management to employees. The analysis method used by the author is Object Oriented Analysis. (OOA). OOA sees problems based on system user objects. With OOA can be created modeling system. The application of OOA in this study uses Unified Modelling Language (UML) diagram. The Unified Modelling Language (UML) diagrams that the authors use are the Use Case Diagram design of the Activity Diagram design, the Sequence Diagram design, and the Class Diagram design. Application development method or Software Development Life Cycle (SDLC) that the author applied is waterfall method. Waterfall method has a special feature that is the entire development process is carried out in sequence starting from the stage of concept planning, modeling, development, testing and maintenance of the system. This analysis found that the existence of Find\&Go application can help in overcoming arrears problems that occur in the company.

Keywords: Caring Teritory Base, Internet, Billing, Analyzes

\section{PENDAHULUAN}

Definisi CTB (Caring Territory Base) pada PT. Telekomunikasi Indonesia secara umum adalah menangani masalah tunggakan pelanggan dan memberikan edukasi kepada pelanggan. Pelanggan PraNPC (Pra Non Productive Customer) yaitu pelanggan yang belum melakukan pembayaran selama 2 bulan, lalu tugas CTB adalah dengan cara mendatangi pelanggan tersebut dan mencari tahu mengapa pelanggan tersebut belum membayar tagihannya.

Dan dalam melakukan kunjungan, selalu ditemui kendala ATK (Alamat Tidak Ketemu). Hal ini disebabkan oleh data alamat yang tertera tidak lengkap dan tidak sesuai lokasi pelanggan. Selama ini CTB menghabiskan banyak waktu untuk berputar-putar mencari alamat. Oleh karena itu, tim berusaha menemukan solusi kendala ATK yang ditemui dilapangan.

Pada saat ini semakin bertambahnya pelanggan yang menggunakan Indihome, bertambah pula tunggakan tagihan serta jangkauan area yang nantinya akan sulit di temukan, guna memenuhi target setiap bulan maka diperlukan metode atau program yang dapat mempermudah baik petugas dilapangan maupun administrator itu sendiri.

Selain itu Menurut McKeown dalam Suyanto (2005:10) teknologi informasi merujuk pada seluruh bentuk teknologi yang digunakan untuk menciptakan, menyimpan, mengubah, dan menggunakan informasi dalam segala bentuknya.

\section{METODE DAN MATERI}

Metode penelitian yang di lakukan untuk menyusun skripsi ini adalah sebagai berikut:

2.1. Metode Analisis

Metode analisis yang digunakan adalah $\quad$ Object $\quad$ Oriented Analisis. (OOA). $O O A$ melihat masalah berdasarkan objek pengguna sistem. Dengan OOA dapat dibuat pemodelan sistem yang sedang berjalan.Penerapan dari $O O$ A dalam penelitian ini menggunakan diagram Unified Modelling Language (UML). 
Jurnal Manajemen Informatika Jayakarta

Volume 1, Nomor 2, April 2021, halaman 73-95
P-ISSN: 2746-5985

e-ISSN: $2797-0930$

DOI: 10.52362/jmijayakarta.v1i2.444

Diagram Unified Modelling Language (UML) yang penulis gunakan adalah rancangan Use Case Diagram rancangan Activity Diagram, rancangan Sequence Diagram, dan rancangan Class Diagram.

\subsection{Metode Pengembangan}

Metode pengembangan aplikasi atau Software Development Life Cycle (SDLC)

yang penulis terapkan adalah

metode waterfall. Metode waterfall memiliki ciri khusus yaitu seluruh proses pengembangan dilakukan secara berurutan yang dimulai dari tahap perencanaan konsep, pemodelan, development, pengujian dan pemeliharaan sistem.

\subsection{Metode Perancangan}

Metode Perancangan sistem yang digunakan adalah Object Oriented Design (OOD). OOD dilakukan berdasarkan hasil analisa OOA. Pada tahap ini dilakukan penentuan arsitektur sistem, kebutuhan perangkat lunk dan perangkat keras, perancangan database sistem dan perancangan interface sistem.

\subsection{Metode Pengujian}

Uji coba dilakukan dengan menggunakan metode Black Box Testing. Penerapan metode tersebut dilakukan dengan membuat skenario uji coba. Berdasarkan skenario uji coba didapatkan hasil dan kesimpulan performa sistem.

\subsection{Landasan Teori}

Definisi sistem menurut Mulyadi (2016:5), Sistem adalah "suatu jaringan prosedur yang dibuat menurut pola yang terpadu untuk melaksanakan kegiatan pokok perusahaan". Berdasarkan pengertian diatas dapat disimpulkan bahwa sistem adalah kumpulan dari komponen-komponen yang saling berkaitan untuk mencapai tujuan perusahaan. Sedangkan menurut Mulyani (2016:2) menyatakan bahwa "sistem bisa diartikan sebagai sekumpulan subsistem, komponen yang saling bekerja sama dengan tujuan yang sama untuk menghasilkan output yang sudah ditentukan sebelumnya".

Dari pemahaman diatas penulis dapat menyimpulkan bahwa sistem adalah kumpulan dari komponen atau elemen-elemen atau sub-subsistem yang saling berkaitan dan bekerja sama melakukan suatu urutan kegiatan yang saling berhubungan untuk mencapai suatu tujuan tertentu.

\subsection{Karakteristik Sistem}

Suatu sistem mempunyai karakteristik atau sifat-sifat tertentu, yaitu mempunyai komponen-komponen (components), batasan sistem (boundary), lingkungan luar sistem (environments), penghubung (interface), masukan (input), keluaran (output), pengolah (process), dan sasaran (objectives).

Adapun karakteristik yang dimaksud adalah sebagai berikut:

a. Komponen Sistem

Suatu sistem terdiri dari sejumlah komponen yang saling berinteraksi yang artinya saling bekerja sama membentuk satu kesatuan. Komponen-komponen sistem tersebut dapat berupa suatu subsistem atau bagianbagian dari sistem.

b. Batasan Sistem (Boundary)

Batasan sistem merupakan daerah yang membatasi antara suatu sistem dengan sistem yang lainnya atau dengan lingkungan luarnya. Batasan sistem ini memungkinkan suatu sistem dipandang sebagai satu kesatuan.

Batasan suatu sistem menunjukan ruang lingkup dari sistem itu sendiri.

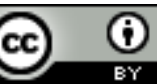


Jurnal Manajemen Informatika Jayakarta

Volume 1, Nomor 2, April 2021, halaman 73-95
P-ISSN: 2746-5985

e-ISSN: $2797-0930$

DOI: 10.52362/jmijayakarta.v1i2.444

a. Lingkungan Luar Sistem (Environment)

Lingkungan luar dari suatu sistem adalah apapun diluar batas dari sistem yang mempengaruhi operasi sistem.

b. Penghubung Sistem (Interface)

Penghubung sistem merupakan media penghubung antara satu subsistem dengan subsistem lainnya.

c. Masukan Sistem (Input)

Masukan adalah bahan atau energi yang dimasukan kedalam sistem. Masukan dapat berupa perawatan (maintenance input) dan masukan sinyal (signal input).

d. Keluaran Sistem (Output)

Keluaran (Output) adalah hasil dari bahan atau energi yang diolah dan diklasifasikan menjadi keluaran yang berguna.

\subsection{Pengolah Sistem}

Pengolah adalah mesin atau mekanisme yang digunakan mengubah masukan menjadi keluaran. Pengolah memiliki peranan yang penting karena disinilah proses perubahan dan penggunaan masukan terjadi sehingga menghasilkan keluaran yang sesuai dengan tujuan sistem

\subsection{Sasaran dan Tujuan Sistem}

Suatu sistem pasti memilik sasaran atau tujuan. Tujuan merupakan hal akhir yang ingin dicapai oleh suatu sistem, sedangkan sasaran merupakan hal-hal yang menjadi objek dan titik fokus untuk meraih tujuan.

\section{Pengertian informasi}

Sistem Informasi (SI) adalah kombinasi dari orang-orang, perangkat keras, perangkat lunak, jaringan komunikasi, sumber daya data, dan kebijakan serta prosedur dalam menyimpan, mendapatkan kembali, mengubah, dan menyebarkan informasi dalam suatu organisasi (Marakas \& O'Brien, 2017)

Terdapat 3 Jenis Perancangan sistem yaitu:

1. Perancangan database.

Sejumlah kumpulan data yang tersimpan di dalam media penyimpanan sekunder. Data - data tersebut diolah menjadi data output/keluaran sistem.

2. Perancangan proses.

Menjelaskan sebuah proses bekerjanya sebuah sistem untuk melakukan pengolahan data input menjadi data output menggunakan fungsi-fungsi yang sudah direncanakan.

3. Perancangan Interface. Bagian software yang bisa dipakai oleh end user yang bisa dilihat pada layar monitor apabila program dijalankan.

Setiap sistem terdiri dari empat unsur, yaitu:

1. Objek, di dalam sistem terdapat sekumpulan objek (fisik/abstrak) dalam bentuk elemen, bagian, atau variabel.

2. Atribut, sesuatu yang menentukan mutu atau sifat kepemilikan suatu sistem dan objeknya.

3. Hubungan internal, setiap elemen saling terikat menjadi satu kesatuan.

4. Lingkungan, tempat atau wilayah dimana sistem berada.

Sedangkan elemen pembentuk suatu sistem dapat dibagi menjadi tujuh bagian, yaitu:

1. Tujuan, sistem dibuat untuk mencapai tujuan (output) tertentu yang ingin dicapai.

2. Masukan, semuanya yang masuk ke dalam sistem akan diproses, baik itu objek fisik maupun abstrak. 
Jurnal Manajemen Informatika Jayakarta

Volume 1, Nomor 2, April 2021, halaman 73-95
P-ISSN: 2746-5985

e-ISSN: $2797-0930$

DOI: 10.52362/jmijayakarta.v1i2.444

3. Proses, yaitu transformasi dari masukan menjadi keluaran yang lebih memiliki nilai, misalnya produk atau informasi. Namun juga bisa dapat berupa hal yang tak berguna, misalnya limbah.

4. Keluaran, ini adalah hasil dari pemrosesan dimana wujudnya bisa dalam bentuk informasi, saran, cetakan laporan, produk, dan lain-lain.

5. Batas, sesuatu yang memisahkan antara sistem dan daerah di luar sistem. Dalam hal batas akan menentukan konfigurasi, ruang lingkup, dan hal-hal lainnya.

6. Pengendalian dan umpan balik, mekanismenya dapat dilakukan dengan memakai feedback terhadap keluaran untuk mengendalikan masukan maupun proses.

7. Lingkungan, segala sesuatu di luar sistem yang berpengaruh pada sistem, baik menguntungkan maupun merugikan.

Pengertian Sistem Menurut Jogianto (2005: 2) mengemukakan bahwa sistem adalah kumpulan dari elemenelemen yang berinteraksi untuk mencapai suatu tujuan tertentu. sistem ini menggambarkan suatu kejadiankejadian dan kesatuan yang nyata adalah suatu objek nyata, seperti tempat, benda, dan orang-orang yang betulbetul ada dan terjadi.

Berdasarkan persyaratan ini, sistem dapat didefinisikan sebagai seperangkat elemen yang digabungkan satu dengan lainnya untuk suatu tujuan bersama. Kumpulan elemen terdiri dari manusia, mesin, prosedur, dokumen, data atau elemen lain yang terorganisir dari elemen-elemen tersebut. Elemen sistem disamping berhubungan satu sama lain, juga berhubungan dengan lingkungannya untuk mencapai tujuan yang telah ditentukan sebelumnya. Konsep ini mengandaikan bahwa di dalam suatu sistem, output dari suatu organisasi diharapkan lebih besar daripada output individual atau output masing-masing bagian.

\section{Pengertian Sistem}

Definisi Sistem Menurut Dr. Ir. Harijono Djojodihardjo (1984: 78)“Suatu sistem adalah sekumpulan objek yang mencakup hubungan fungsional antara tiap-tiap objek dan hubungan antara ciri tiap objek, dan yang secara keseluruhan merupakan suatu kesatuan secara fungsional.”.

Sedangkan Definisi Sistem MenurutDr. Ir. Harijono Djojodihardjo (1984: 78)“Suatu sistem adalah sekumpulan objek yang mencakup hubungan fungsional antara tiap-tiap objek dan hubungan antara ciri tiap objek, dan yang secara keseluruhan merupakan suatu kesatuan secara fungsional.”

Dari beberapa pengertian diatas, dapat disimpulkan bahwa sistem merupakan kumpulan dari unsur atau bagian yang berhubungan dan bekerjasama untuk mencapai tujuan tertentu yang diinginkan. Unsur atau bagian tersebut bisa merupakan prosedur-prosedur atau subsistem-subsistem yang terkumpul dan diatur sedemikian rupa untuk mencapai suatu sistem yang diinginkan.

\section{Karakteristik Sistem}

Menurut Jogianto (2005: 2) menyebutkan bahwa sebuah sistem memiliki karakteristik atau sifat-sifat tertentu, diantaranya yaitu:

a. Komponen Sistem (Component) Komponen-komponen sistem tersebut dapat berupa suatu bentuk subsistem. Setiap sistem memiliki sifat dari sistem yang menjalankan suatu fungsi tertentu dan mempengaruhi proses sistem secara keseluruhan.

b. Batasan Sistem (Boundary) Ruang lingkup sistem merupakan daerah yang membatasi antara sistem dengan sistemyang lain atau sistem dengan lingkungan luarnya. Batasan sistem ini memungkinkan suatu sistem dipandang sebagai satu kesatuan yang tidak dapat dipisahkan.

c. Lingkungan Luar Sistem(Environment) Bentuk apapun yang ada diluar ruang lingkup atau batasan sistem yang mempengaruhi operasi sistem tersebut disebut lingkungan luar sistem. 13 Lingkungan luar sistem inidapat bersifat menguntungkan dan dapat juga bersifat merugikan sistem tersebut, 
Jurnal Manajemen Informatika Jayakarta

Volume 1, Nomor 2, April 2021, halaman 73-95
P-ISSN: 2746-5985

e-ISSN: 2797-0930

DOI: 10.52362/jmijayakarta.v1i2.444

d. Penghubung Sistem (Interface) Hubungan sistem adalah hubungan yang terjadi antar subsistem dengan subsistem lainnya yang setingkat atau antara subsistem yang lebih besar. Hubungan sistem terdiri dari dua jenis yaitu hubungan vertikal dan hubungan horizontal. Hubungan vertikal adalah hubungan yang terjadi antara subsistem dengan subsistem lainnya yang lebih besar atau lebih tinggi tingkatannya. Hubungan horizontal menunjukkan hubungan antara subsistem dengan subsistem lainnya yang setingkat.

e. Masukan Sistem (Input) Energi yang dimasukkan ke dalam sistem disebut masukan sistem, yang dapat berupa pemeliharaan (maintenance input) dan sinyal (signal input).

f. Keluaran Sistem (Output) Hasil energi yang diolah dan diklasifikasikan menjadi keluaran yang berguna. Keluaran ini dapat mennjadi masukan bagi subsistem yang lain seperti sistem informasi. Keluaran yang dihasilkan adalah informasi.

g. Pengolah Sistem (Process) Suatu sistem dapat mempunyai suatu proses yang akan mengubah masukan menjadi keluaran.

h. Sasaran (Objectivies) dan Tujuan Sistem memiliki tujuan dan sasaran yang pasti dan bersifat deterministik. Kalau suatu sistem tidak memiliki sasaran maka operasi.

\section{Klasifikasi Sistem}

Menurut Menurut Jogiyanto HM., (1999: 687), Sistem dibagi menjadi beberapa bentuk, antara lain:

a. Sistem Abstrak

Sistem abstrak adalah sistem yang berupa pemikiran atau ide ide yang tidak tampak secara fisik. Sedangkan sistem fisik merupakan sistem yang ada secara fisik seperti sistem komputer, sistem penjualan, sistem administrasi dan lain sebagainya.

b. Sistem Fisik

Sistem Fisik adalah sistem yang ada secara phisik

c. Sistem Alamiah

Sistem alamiah adalah sistem yang terjadi melalui proses alam, tidak dibuat oleh manusia, misalnya sistem perputaran bumi, terjadinya siang dan malam, dan pergantian musim. Sedangkan sistem buatan manusia merupakan sistem yang melibatkan hubungan manusia dengan mesin, yang disebut dengan human machine sistem.

4. Sistem Buatan

Sistem Buatan adalah sistem yang dirancang oleh manusia.

5. Sistem Deterministik

Sistem deterministik adalah sistem yang beroprasi dengan tingkah laku yang dapat diprediksi. Sedangkan sistem probabilistik adalah sistem yang kondisi masa depannya tidak dapat diprediksi, karena mengandung unsur probabilitas.

6. Sistem Probabilistik

sistem yang kondisi masa depannya tidak dapat diprediksi karena mengandung unsur probabilitas

7. Sistem Terbuka

Sistem tertutup merupakan sistem yang tidak berhubungan dan tidak dipengaruhi oleh lingkungan luarnya, sedangkan sistem terbuka adalah sistem yang berhubungan dan dipengaruhi oleh lingkungan luarnya, yang menerima masukan dan menghasilkan keluaran untuk subsistem lainnya.

8. Sistem Tertutup

Sistem Tertutup adalah sistem yang tidak berhubungan dengan lingkungan luarnya.

9. Konsep Dasar Informasi.

Menurut Tata Sutabri (2012 : 22) informasi adalah data yang telah diklasifikasikan atau diolah atau diinterpretasikan untuk digunakan dalam proses pengambilan keputusan.

Informasi juga disebut data yang diproses atau data yang memiliki arti. Informasi merupakan data yang telah diproses sedemikian rupa sehingga meningkatkan pengetahuan seseorang yang menggunakannya.

\section{Kualitas Informasi}




\section{Jurnal Manajemen Informatika Jayakarta \\ P-ISSN: 2746-5985 \\ Volume 1, Nomor 2, April 2021, halaman 73-95 \\ e-ISSN: $2797-0930$}

DOI: 10.52362/jmijayakarta.v1i2.444

Menurut Tata Sutabri (2012 : 33) kualitas dari informasi tergantung dari tiga hal yaitu :

a. Akurat (accurate)

b. Informasi harus bebas dari kesalahan dan tidak bias atau menyesatkan.

c. Tepat waktu (timelines)

d. Informasi yang sampai kepada penerima tidak boleh terlambar. Informasi yang usang tidak akan mempuyai nilai lagi, karena informasi merupakan landasan didalam pengambilan keputusan.

e. Relevan (relevance)

f. Informasi tersebut mempuyai manfaat untuk pemakainya, relevansi informasi setiap orang berbeda.

2. Nilai Informasi

Menurut Tata Sutabri (2012: 31) nilai informasi didasarkan atas sepuluh sifat yaitu :

a. Mudah diperoleh

Sifat ini menunjukan kemudahan dan kecepatan untuk meperoleh informasi.

b. Luas dan lengkap

Sifat ini menunjukan kelengkapan isi informasi. Hal ini tidak hanya mengenai volumennya, akan tetapi juga mengenai keluaran informasi.

c. Ketelitian

Sifat ini berhubungan dengan tingkat kebebasan dari kesalahan keluaran informasi.

d. Kecocokan

Sifat ini menunjukan seberapa baik keluaran informasi dalam hubungannya dengan permintaan para pemakai.

e. Ketepatan waktu informasi.

Sifat ini berhubungan dengan waktu yang dilalui, lebih pendek dari siklus untuk mendapatkan

f. Kejelasan

Sifat ini menunjukan tingkat kejelasan informasi, informasi hendaknya terbebas dari istilahistilah yang tidak jelas.

g. Keluwesan

Sifat ini berhubungan dengan apakah informasi tersebut dapat digunakan untuk membuat lebih dari suatu keputusasn, tetapi juga apakah dapat digunakan untuk lebih dari seseorang pengambil keputusan

h. Dapat dibuktikan

Sifat ini menunjukan sejauh mana informasi itu dapat diuji oleh beberapa pemakai hingga sampai didapatkan kesimpulan yang sama.

i. Tidak ada prasangka

Sifat ini berhubungan dengan ada tidaknya keinginan untuk mengubah informasi tersebut guna mendapatkan kesimpulan yang telah diarahkan sebelumnya.

j. Dapat diukur

Sifat ini menunjukan hakikat informasi yang dihasilkan oleh sistem informasi formal.

\section{A. Teori Metode Terkait}

\section{Unified Modeling Language (UML)}

Verdi Yasin (2012:194) dalam bukunya yang berjudul Rekayasa Perangkat Lunak Berorientasi Objek menyatakan : "Unifield Modelling Language (UML) adalah sebuah "bahasa" yang telah menjadi standar dalam industri untuk visualisasi, merancang dan mendokumentasikan sistem piranti lunak. UML menawarkan sebuah standar untuk merancang model sebuah sistem”. Sedangkan Menurut Herlawati dan Widodo (2011:10), UML merupakan singkatan dari "Unified Modelling Language" adalah suatu bahasa yang sudah menjadi standar pada 
DOI: $10.52362 /$ jmijayakarta.v1i2.444

visualisasi, perancangan dan juga pendokumentasian sistem software. Adapun beberapa jenis diagram dari UML sebagai berikut :

1. Use case diagram

Use case diagram menggambarkan fungsionalitas yang diharapkan dari sebuah sistem. Yang ditekankan adalah "apa" yang diperbuat system, dan bukan "bagaimana". Sebuah use case merepresentasikan sebuah interaksi antara aktor dengan system.

Menurut Rosa dan M. Shalahudin (2014:155) adapun simbol dari use case adalah sebagai berikut :

Tabel 2.2 Simbol Use Case Diagram

\begin{tabular}{|c|c|}
\hline Simbol & Keterangan \\
\hline 1. Use Case & $\begin{array}{l}\text { Fungsionalitas yang disediakan sistem sebagai } \\
\text { unit-unit yang saling bertukar pesan antar unit } \\
\text { atau aktor; biasanya dinyatakan dengan } \\
\text { menggunakan kata kerja frase nama use case. }\end{array}$ \\
\hline 2. Aktor/actor & $\begin{array}{l}\text { Orang, proses, atau sistem lain yang berinteraksi } \\
\text { dengan sistem informasi yang akan dibuat di luar } \\
\text { sistem informasi yang akan dibuat itu sendiri, jadi } \\
\text { walaupun simbol dari aktor adalah gambar orang, } \\
\text { tapi aktor belum tentu merupakan orang, biasanya } \\
\text { dinyatakan menggunakan kata benda di awal frase } \\
\text { nama actor }\end{array}$ \\
\hline 3. Assosiasi/association & $\begin{array}{l}\text { Komunikasi antara aktor dan use case yang } \\
\text { berpartisilpasi pada use case atau use case memiliki } \\
\text { interaksi dengan aktor. }\end{array}$ \\
\hline$----\cdot\langle<$ extend $>>---\rangle$ & $\begin{array}{l}\text { Relasi use case tambahan kesebuah use case dimana } \\
\text { use case yang ditambahkan dapat berdiri sendiri } \\
\text { walau tanpa use case tambahan itu, mirip dengan } \\
\text { prinsip inheritance pada pemrograman berorientasi } \\
\text { objek, biasanya use case tambahan memiliki nama } \\
\text { depan yang sama dengan use case yang } \\
\text { ditambahkan, missal: }\end{array}$ \\
\hline
\end{tabular}


DOI: 10.52362/jmijayakarta.v1i2.444

Lanjutan Tabel 2.2 Simbol Use Case Diagram

\begin{tabular}{|c|c|}
\hline Simbol & Keterangan \\
\hline & $\begin{array}{l}\text { Relasi use case tambahan kesebuah use case } \\
\text { dimana use case yang ditambahkan dapat } \\
\text { berdiri sendiri walau tanpa use case tambahan } \\
\text { itu, mirip dengan prinsip inheritance pada } \\
\text { pemrograman berorientasi objek, biasanya use } \\
\text { case tambahan memiliki nama depan yang } \\
\text { sama dengan use case yang ditambahkan, } \\
\text { missal : } \\
\text { Validasi user name } \\
\text { Validasi user } \\
\text { < } \\
\text { Validend > } \\
\text { Vasi sidik jari } \\
\text { Arah panah mengarah pada use case yang } \\
\text { extend-nya merupakan jenis yang sama dengan } \\
\text { use case yang menjadi induknya. }\end{array}$ \\
\hline 5. Generalisasi/generalization & $\begin{array}{l}\text { Hubungan generalisasi dan spesialisasi } \\
\text { (umum-khusus) antara dua buah use case } \\
\text { dimana fungsi yang satu adalah fungsi yang } \\
\text { lebih umum dari lainnya, misalnya: }\end{array}$ \\
\hline
\end{tabular}


DOI: 10.52362/jmijayakarta.v1i2.444

Lanjutan Tabel 2.2 Simbol Use Case Diagram

\begin{tabular}{|c|c|}
\hline Simbol & Keterangan \\
\hline & $\begin{array}{l}\text { arah panah mengarah pada use case yang } \\
\text { menjadi generalisasinya (umum) }\end{array}$ \\
\hline $\begin{array}{l}\text { 6. Menggunakan / include / uses } \\
\frac{<<\text { include }>>}{<<\text { uses }>>>}>\end{array}$ & $\begin{array}{l}\text { Relasi use case tambahan ke sebuah use case } \\
\text { dimana use case yang ditambahkan } \\
\text { memerlukan use case ini untuk menjalankan } \\
\text { fungsinya atau sebagai syarat dijalankan use } \\
\text { case ini Ada dua sudut pandang yang cukup } \\
\text { besar mengenai include di use case: } \\
\text { - Include berarti use case yang ditambahkan } \\
\text { akan selalu di panggil saat use case } \\
\text { tambahan dijalankan, missal pada kasus } \\
\text { berikut: }\end{array}$ \\
\hline
\end{tabular}

Sumber : Rosa A.S dan M. Shalahudin (2014:156)

\section{Class diagram}

Class Diagram adalah sebuah spesifikasi yang jika diinstansiasi akan menghasilkan sebuah objek dan merupakan inti dari pengembangan dan desain berorientasi objek. Class menggambarkan keadaan (atribut/property) suatu system, sekaligus menawarkan layanan untuk memanipulasi keadaan tersebut (metoda/fungsi). Class diagram menggambarkan struktur dan deskripsi class, package dan objek beserta hubungan satu sama lain seperti containment, pewarisan, asosiasi, dan lain-lain.

Adapun simbol yang digunakan dalam classdiagram adalah sebagai berikut :

Tabel 2.3 Simbol Class Diagram

\begin{tabular}{|l|l|}
\hline Simbol & Keterangan \\
\hline
\end{tabular}


DOI: 10.52362/jmijayakarta.v1i2.444

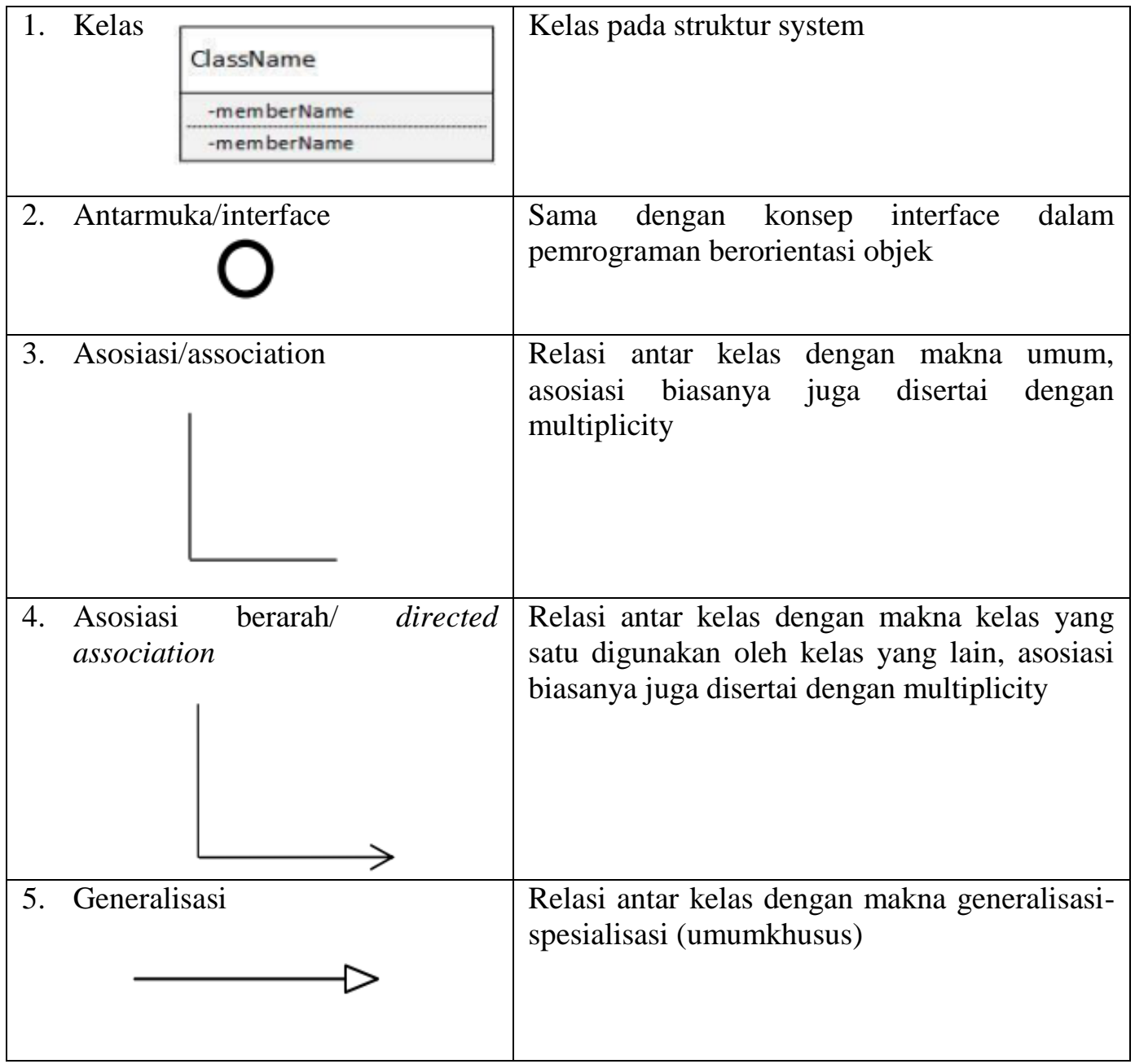

Lanjutan Tabel 2.3 Simbol Class Diagram

\begin{tabular}{|c|c|}
\hline Simbol & Keterangan \\
\hline 6. Kebergantungan/dependensi & $\begin{array}{l}\text { Relasi antar kelas dengan } \\
\text { kebergantungan antar kelas. }\end{array}$ \\
\hline 7. Agregasi/aggregation & $\begin{array}{l}\text { Relasi antar kelas dengan makna semua- } \\
\text { bagian (whole-part). }\end{array}$ \\
\hline
\end{tabular}

Sumber : Rosa A.S dan M. Shalahudin (2014:146) 


\section{Jurnal Manajemen Informatika Jayakarta \\ P-ISSN: 2746-5985 \\ Volume 1, Nomor 2, April 2021, halaman 73-95 \\ e-ISSN: 2797-0930}

DOI: 10.52362/jmijayakarta.v1i2.444

\section{Activity diagram}

Activity diagram menggambarkan berbagai alir aktivitas dalam system yang sedang dirancang, bagaimana masing-masing alir berawal, decision yang mungkin terjadi, dan bagaimana mereka berakhir. Activity diagram juga dapat menggambarkan proses parallel yang mungkin terjadi pada beberapa eksekusi. Activity diagram merupakan state diagram khusus, di mana sebagian besar state adalah action dan sebagian besar transisi menggambarkan behavior internal sebuah system (dan interaksi antar subsistem)di-trigger oleh selesainya state sebelumnya (internal processing).

Adapun simbol yang digunakan dalam Activity diagram adalah sebagai berikut :

Tabel 2.4 Simbol Activity Diagram

\begin{tabular}{|c|c|}
\hline SIMBOL & KETERANGAN \\
\hline 1. Status awal & $\begin{array}{l}\text { Status awal aktivitas sistem, sebuah } \\
\text { diagram aktivitas memiliki sebuah status } \\
\text { awal. }\end{array}$ \\
\hline 2. Aktivitas & 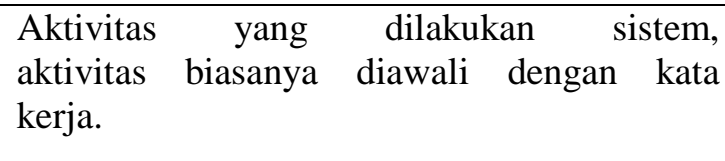 \\
\hline 3. Percabangar & $\begin{array}{l}\text { Asosiasi percabangan dimana jika ada } \\
\text { pilihan aktivitas lebih dari satu. }\end{array}$ \\
\hline 4. $\quad$ Penggabung & $\begin{array}{l}\text { Asosiasi penggabungan dimana lebih dari } \\
\text { satu aktivitas digabungkan menjadi satu. }\end{array}$ \\
\hline 5. Status akhir & $\begin{array}{l}\text { Status akhir yang } \text { dilakukan oleh sistem, } \\
\text { sebuah diagram aktivitas memiliki } \\
\text { sebuah status akhir. }\end{array}$ \\
\hline 6. $\quad$ Swimlane & \begin{tabular}{ll} 
Memisahkan & \multicolumn{2}{c}{ organisasi bisnis yang } \\
bertanggunga & jawab terhadap aktivitas \\
yang terjadi. &
\end{tabular} \\
\hline
\end{tabular}

Sumber : Rosa A.S dan M. Shalahudin (2014:146)

\section{Sequence diagram}

Sequence diagram menggambarkan interaksi antar objek di dalam dan disekitar system (termasuk pengguna, display, dan sebagainya) berupa message yang digambarkan terhadap waktu. Sequence diagram biasa digunakan untuk menggambarkan skenario atau rangkaian langkah-langkah yang dilakukan sebagai respons dari sebuah event untuk menghasilkan output tertentu. 
DOI: 10.52362/jmijayakarta.v1i2.444

Adapun simbol yang digunakan dalam Sequance Diagram adalah sebagai berikut :

Tabel 2.5 Simbol Sequance Diagram

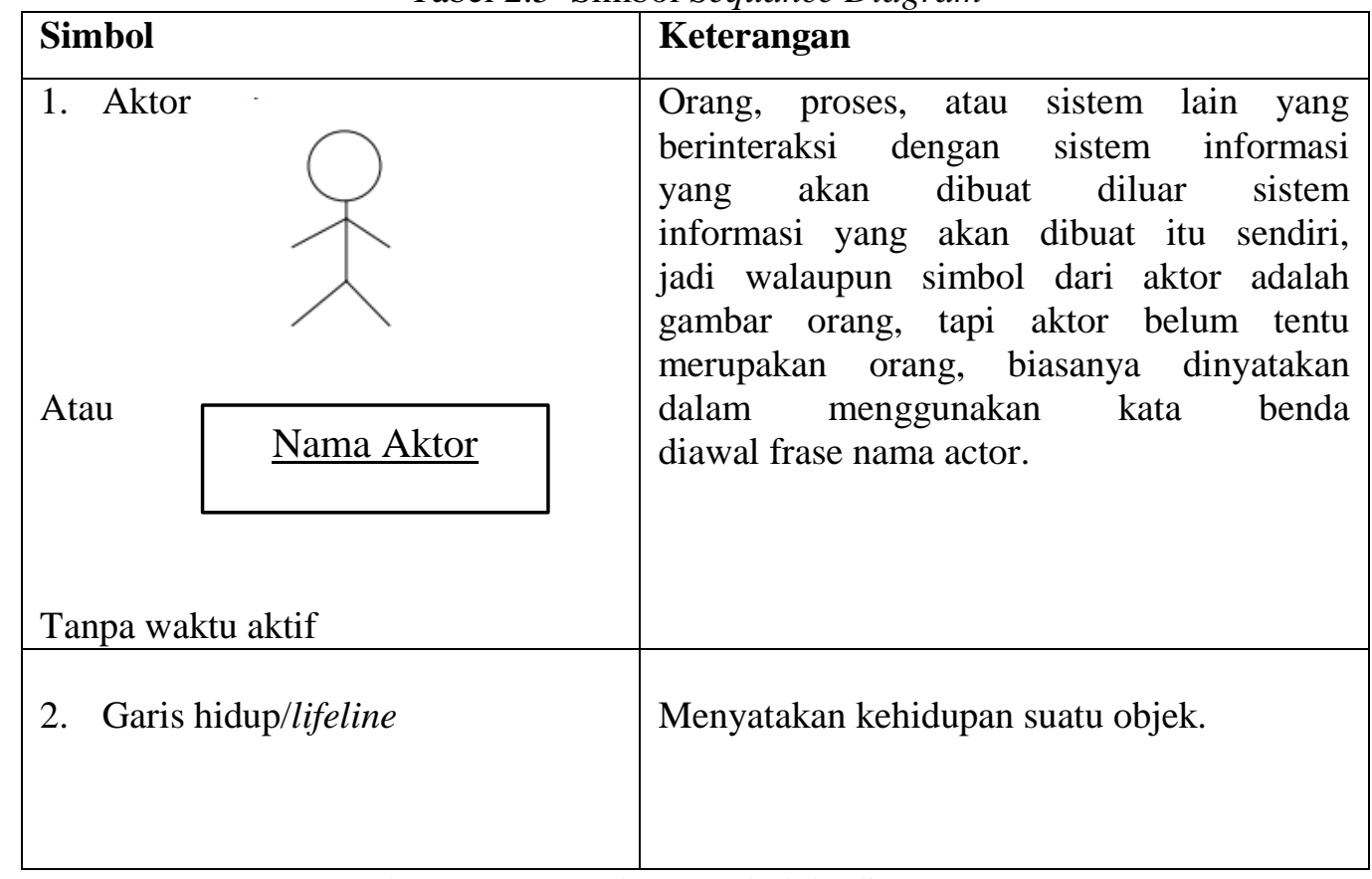

Sumber: Rosa A.S dan M. Shalahudin (2014:165)

Lanjutan Tabel 2.5 Simbol Sequance Diagram

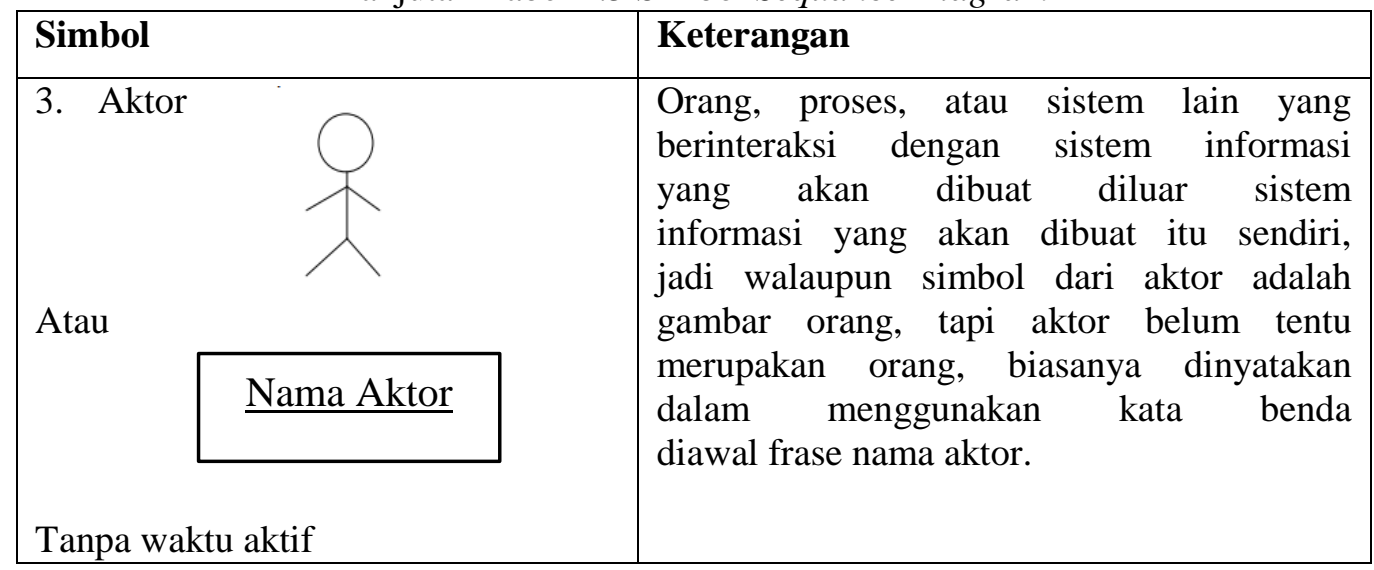


DOI: 10.52362/jmijayakarta.v1i2.444

\begin{tabular}{|c|c|}
\hline 4. Garis hidup/lifeline & Menyatakan kehidupan suatu objek. \\
\hline $\begin{array}{l}\text { 5. } \text { Objek } \\
\qquad \text { Nama Objek : nama kelas }\end{array}$ & $\begin{array}{l}\text { Menyatakan objek yang berinteraksi } \\
\text { pesan. }\end{array}$ \\
\hline 6. Waktu aktif & $\begin{array}{l}\text { Menyatakan objek dalam keadaan } \\
\text { aktif dan berinteraksi, semuanya yang } \\
\text { terhubungdengan waktu aktif ini } \\
\text { adalah sebuah tahapan yang dilakukan } \\
\text { di dalamnya, misalnya } \\
\qquad \begin{array}{l}\text { 2: cekStatusLogin() } \\
\text { Maken() }\end{array} \\
\begin{array}{l}\text { Milakukan didalam metode login(). Aktor } \\
\text { tidak memiliki waktu aktif. }\end{array}\end{array}$ \\
\hline
\end{tabular}

Lanjutan Tabel 2.5 Simbol Sequance Diagram

\begin{tabular}{|l|l|}
\hline Simbol & Keterangan \\
\hline 7. Pesan tipe create & $\begin{array}{l}\text { Menyatakan suatu objek membuat objek } \\
\text { yang lain, arah panah mengarah pada }\end{array}$ \\
& objek yang dibuat
\end{tabular}


DOI: 10.52362/jmijayakarta.v1i2.444

\begin{tabular}{|c|c|}
\hline 8. Pesan tipe call & $\begin{array}{l}\text { Menyatakan suatu objek memanggil } \\
\text { operasi/metode yang ada pada objek lain } \\
\text { atau dirinya sendiri, } \\
\text { Arah panah mengarah pada objek yang } \\
\text { memiliki operasi/metode, karena ini } \\
\text { memanggil operasi/metode maka } \\
\text { operasi/metode yang dipanggil harus ada } \\
\text { pada diagram kelas sesuai dengan kelas } \\
\text { objek yang berinteraksi. }\end{array}$ \\
\hline $\begin{array}{l}\text { 9. Pesan tipe send } \\
1: \text { masukkan }\end{array}$ & $\begin{array}{l}\text { Menyatakan bahwa suatu objek } \\
\text { mengirimkan data/masukkan/informasi } \\
\text { ke objek lainnya, arah panah mengarah } \\
\text { pada objek yang dikirim. }\end{array}$ \\
\hline $\begin{array}{l}\text { 10. Pesan tipe return } \\
\qquad 1: \text { keluaran }\end{array}$ & $\begin{array}{l}\text { Menyatakan bahwa suatu objek yang } \\
\text { telah menjalankan suatu operasi atau } \\
\text { metode menghasilkan suatu kembalian } \\
\text { keobjek tertentu, arah panah mengarah } \\
\text { padaobjek yang menerima kembalian. }\end{array}$ \\
\hline
\end{tabular}

Lanjutan Tabel 2.5 Simbol Sequance Diagram

\begin{tabular}{|l|l|}
\hline Simbol & Keterangan \\
\hline 11. Pesan tipe destroy & $\begin{array}{l}\text { Menyatakan suatu objek mengakhiri } \\
\text { hidup objek yang lain, arah panah } \\
\text { mengarah pada objek yang diakhiri, } \\
\text { sebaliknya jika ada create maka ada } \\
\text { destroy. }\end{array}$ \\
\hline
\end{tabular}

Sumber : Rosa A.S dan M. Shalahudin (2014:165)

\section{HASIL DAN PEMBAHASAN}


Jurnal Manajemen Informatika Jayakarta

Volume 1, Nomor 2, April 2021, halaman 73-95
P-ISSN: 2746-5985

e-ISSN: $2797-0930$

DOI: 10.52362/jmijayakarta.v1i2.444

Pada proses wawancara dan observasi penulis menemukan permasalahan pada pelaporan tim CTB di lapangan yaitu banyak tidak ditemukannya alamat pelanggan praNPC dan juga banyak alamat yang tidak dilengkapi detail nomor rumah, nomor RT dan nomor RW. Sehingga menyebabkan beberapa masalah yang telah penulis rangkum dibawah ini:

a.Terjadinya revenue loss akibat pelanggan praNPC tidak melakukan pembayaran.

b.Tim CTB tersesat pada saat menuju lokasi yang memiliki detail tidak lengkap.

c.Tim CTB menghabiskan waktu yang cukup banyak untuk mencari alamat rumah dari sistem ataupun menunggu mendapatkan alamat detail dari pihak STO.

d.Mengakibatkan target yang didapatkan petugas menurun

Berdasarkan permasalahan yang terjadi tersebut, diperlukan suatu sistem yang dapat melakukan pencarian alamat pelanggan berdasarkan koordinat sehingga dapat ditemukan dengan mudah.

\subsection{Analisis Proses Sistem Berjalan (SWOT)}

Analisa ini didasarkan pada hubungan atau interaksi antara unsur-unsur internal, yaitu kekuatan (strength) dan kelemahan (Weakness), terhadap unsur-unsur eksternal yaitu peluang (opportunities) dan ancaman (Treats).

Tabel 3. 2 Detail Analisis SWOT

\begin{tabular}{|c|c|}
\hline STRENGTH (S) & $W E A K N E S S(\mathrm{~W})$ \\
\hline $\begin{array}{l}\text { Dukungan dari manajemen untuk merancang seb } \\
\text { uah sistem. } \\
\text { Tersedianya data lengkap dari pihak STO sehing } \\
\text { ga dapat } \\
\text { diintegrasikan ke sistem baru. }\end{array}$ & $\begin{array}{l}\text { Pekerjaan yang tidak efektif, efisien, } \\
\text { dan cukup lama karena pegawai kesulitan dalam mencari } \\
\text { alamat pelanggan. }\end{array}$ \\
\hline OPPURTUNITIES $(\mathrm{O})$ & THREATS (T) \\
\hline $\begin{array}{l}\text { Membangun sistem tracking lokasi pelanggan. } \\
\text { Sistem mempermudah pekerjaan tim CTB dalam } \\
\text { menindaklanjuti pelanggan yang terdapat } \\
\text { kendala saat pembayaran. }\end{array}$ & $\begin{array}{l}\text { Menciptakan sistem tracking lokasi pelanggan yang } \\
\text { mudah dipahami. }\end{array}$ \\
\hline
\end{tabular}

Analisis Kebutuhan Organisasi

3.3 Analisis Kebutuhan Data atau Informasi

Penelitian ini membutuhkan data alamat pelanggan praNPC lengkap yang terdapat di pihak STO.

Analisis Software atau Hardware

Dalam pembangunan atau development sistem FIND \& GO membutuhkan beberapa perangkat keras dan perangkat lunak. Perangkat keras yang perlukan yaitu Monitor, Keyboard, Mouse,

Personal Computer (PC) dan handphone dengan operasi sistem android. Beberapa spesifikasi

yang direkomendasikan untuk Personal Computer $(P C)$ adalah sebagai berikut:

1. Minimal prosesor intel celeron Dual Core $2,20 \mathrm{GHz}$

2.Minimal RAM 2 GB

3.Minimal Hard disk $250 \mathrm{~GB}$

Perangkat lunak yang dibutuhkan adalah sebagai berikut:

1. Operating system windows 7

2. XAMPP versi 5.6 
DOI: $10.52362 /$ jmijayakarta.v1i2.444

3. Microsoft Visual Studio atau Notepad ++

4. Android Studio versi 4.1

Spesifikasi Handphone yang dibutuhkan:

1. Android versi Kitkat 4.4

2. RAM 2 GB

\section{IMPLEMENTASI}

Analisa Kebutuhan

Tahap untuk mengidentifikasi apa saja yang dilakukan oleh sistem baru, apa yang dibutuhkan dan diinginkan pengguna dengan sistem baru.

A. Kebutuhan Pengguna

Dalam aplikasi ini hanya terdapat satu pengguna yang berinteraksi dalam lingkungan sistem yaitu user CTB (Caring Territory Based). scenario seperti berikut :

Analisa kebutuhan user

a) User dapat melihat koordinat rumah pelanggan praNPC

b) User dapat melihat koordinat rumah pelanggan praNPC berdasarkan PIC CTB

c) User dapat melihat data pelanggan

d) User dapat melihat garis petunjuk menuju rumah customer

B. Kebutuhan Sistem

Kebutuhan sistem untuk pengembangan aplikasi adalah sebagai berikut :

1) Setelah mendownload aplikasi User CTB dapat melihat titik - titik WO masing - masing CTB di halaman utama.

2) User dapat melihat informasi detail customer setelah melakukan pemilihan icon di dalam peta.

3) User dapat memunculkan garis directions sebagai petunjuk arah untuk menuju ke rumah customer.

A. Rancangan Diagram Use Case

Use Case Sistem Informasi Pelacakan Pelanggan praNPC PT Telekomunikasi Indonesia

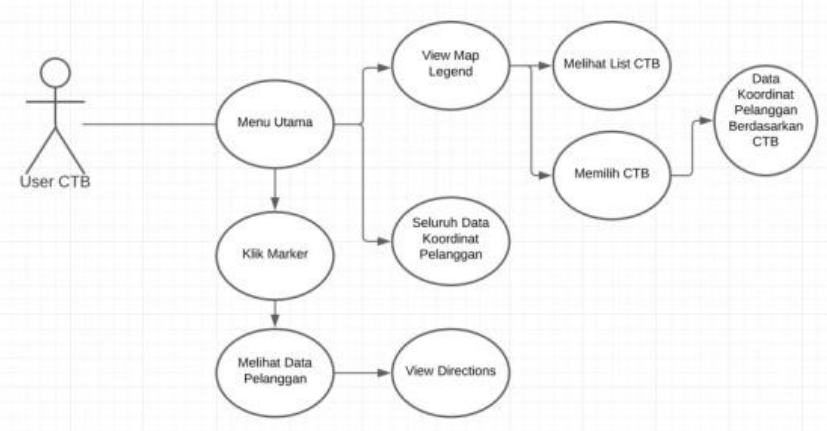

Gambar.IV. 1 Use Case Sistem Informasi Pelacakan Pelanggan praNPC PT Telekomunikasi Indonesia

Tabel.IV.1

Deskripsi Use Case Sistem Informasi Pelacakan Pelanggan praNPC PT Telekomunikasi Indonesia

Use Case 
DOI: 10.52362/jmijayakarta.v1i2.444

\begin{tabular}{|l|l|}
\hline Use Case Name & $\begin{array}{l}\text { Use Case Sistem informasi pelacakan pelanggan praNPC PT } \\
\text { Telekomunikasi Indonesia }\end{array}$ \\
\hline Requirements & User CTB dapat memonitoring seluruh lokasi pelanggan praNPC \\
\hline Goal & $\begin{array}{l}\text { User CTB dapat dengan mudah menemukan } \\
\text { lokasi rumah pelanggan praNPC }\end{array}$ \\
\hline Pre-Conditions & $\begin{array}{l}\text { User menjalankan sistem informasi pelacakan } \\
\text { pelanggan praNPC PT.Telekomunkasi Indonesia }\end{array}$ \\
\hline Post-Conditions & Memonitoring lokasi pelanggan praNPC \\
\hline Failed end Condition & Lokasi pelanggan tidak ditemukan \\
\hline Actors & User \\
\hline Main Flow/ \\
Basic Path & $\begin{array}{l}\text { User dapat melihat koordinat rumah seluruh pelanggan praNPC } \\
\text { User dapat melihat list CTB } \\
\text { User dapat memilih CTB } \\
\text { User dapat melihat koordinat } \\
\text { pelanggan praNPC berdasarkan PIC CTB } \\
\text { User dapat melihat informasi Pelanggan }\end{array}$ \\
\hline $\begin{array}{l}\text { Alternate Flow/ } \\
\text { Invariant } A\end{array}$ & - \\
\hline
\end{tabular}


DOI: 10.52362/jmijayakarta.v1i2.444

\section{Rancangan Tampilan Sistem Informasi Pelacakkan Pelanggan praNPC PT Telekomunikai Indonesia}

a) Implementasi Halaman Utama

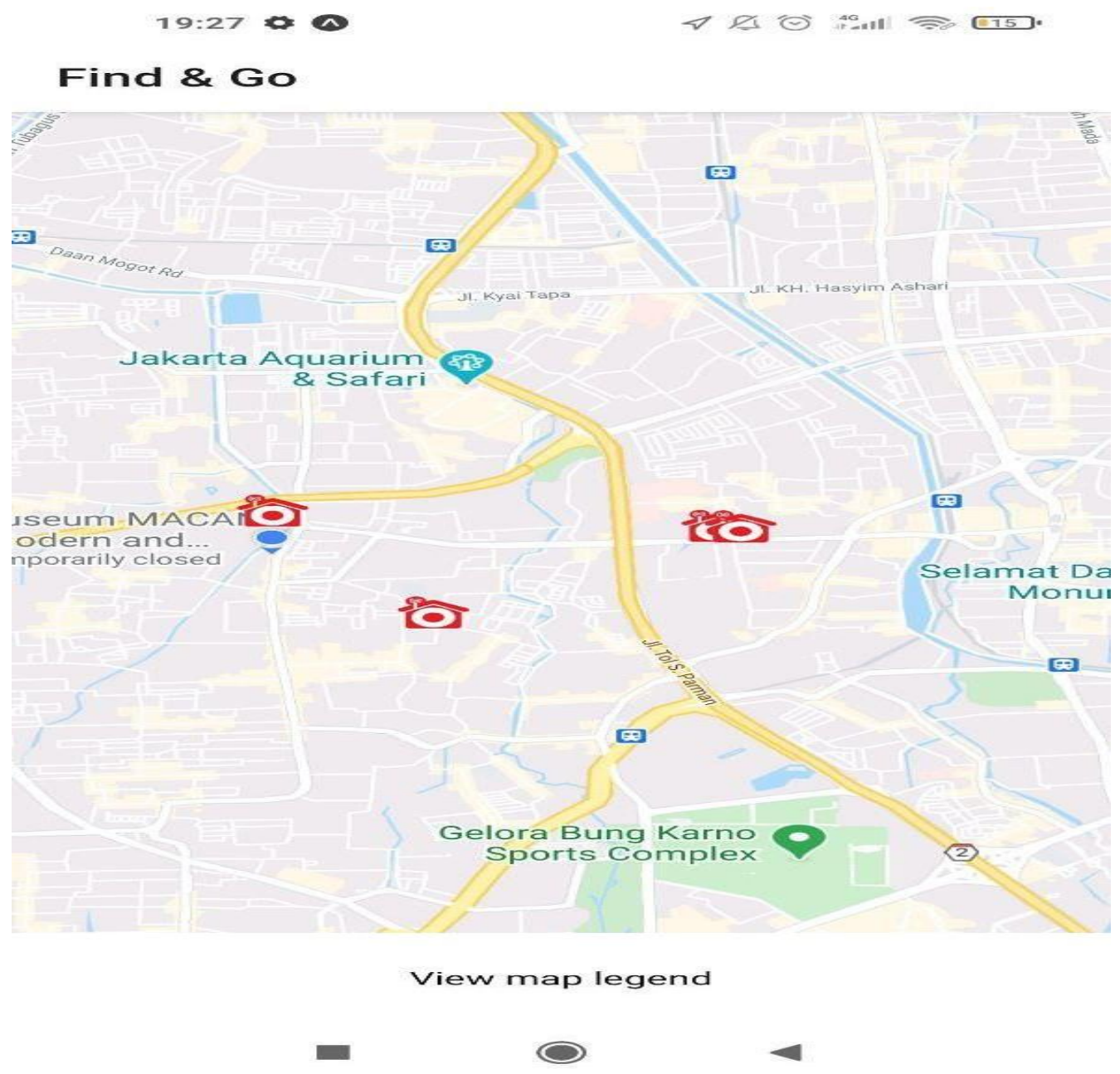

Gambar IV.19. Implementasi Halaman Utama

Halaman utama pada Sistem Informasi Pelacakkan Pelanggan praNPC PT Telekomunikasi Indonesia dapat dilihat pada Gmbar IV.19 Terdapat tampilan peta dan icon PT Telekomunikasi Indonesia yang dimaksud sebagai titik lokasi pelanggan praNPC. 
DOI: 10.52362/jmijayakarta.v1i2.444

b) Implementasi Halaman List Data CTB

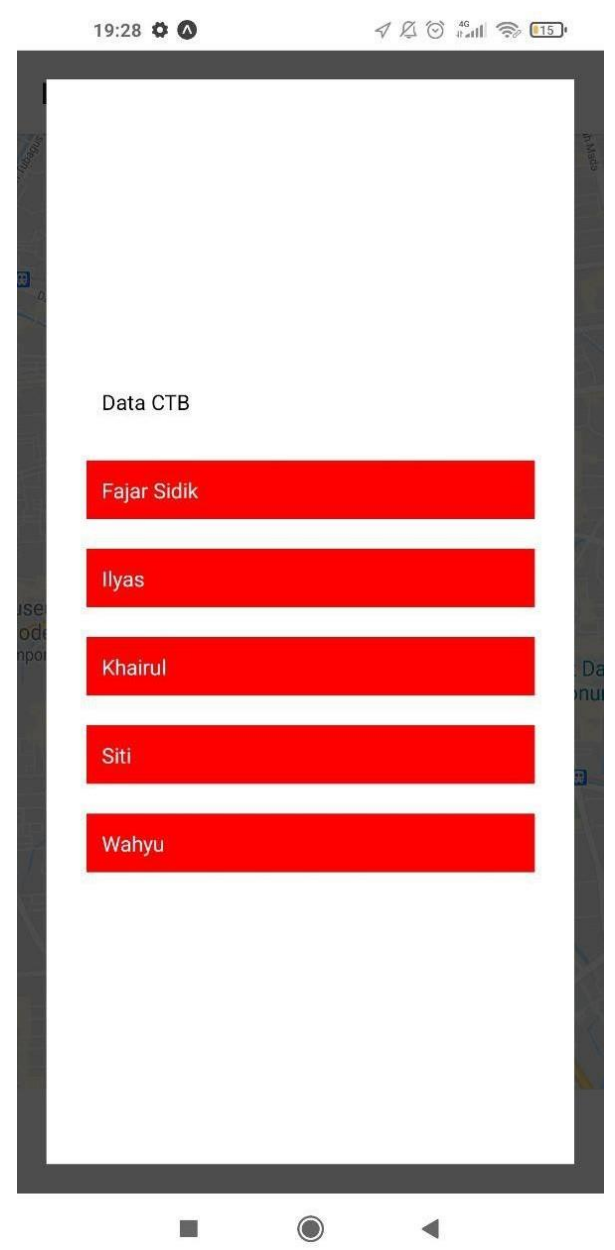

Gambar IV.20. Implementasi Halaman List Data CTB

Setelah pengguna menekan tombol "View Map Legend" maka akan muncul tampilan halaman list data CTB yang dapat di lihat pada Gambar IV.20. Halaman list data CTB adalah daftar pegawai CTB dimana jika dipilih salah satu list tersebut maka akan memunculkan data pelanggan praNPC sesuai dengan CTB yang dipilih.

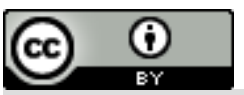


DOI: 10.52362/jmijayakarta.v1i2.444

c) Implementasi Halaman Data Pelanggan praNPC

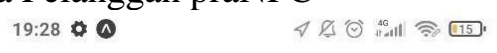

\section{Find \& Go}

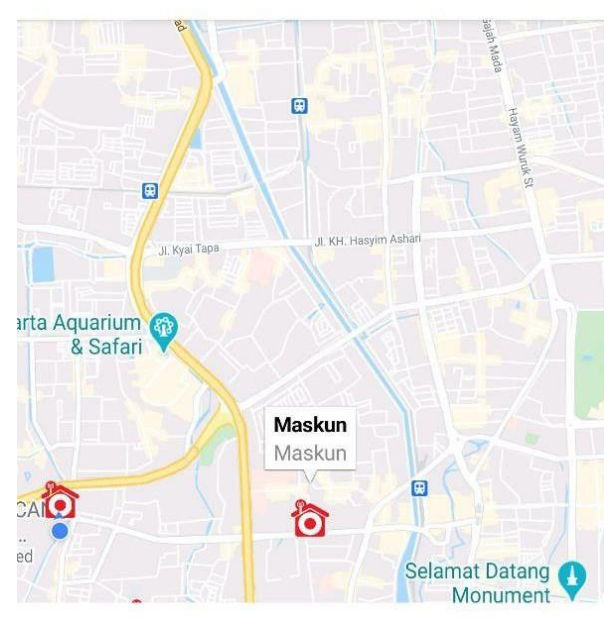

Customer Information

\section{Nama: Maskun}

Alamat: Jalan Ks. Tubun 2B No.5-7A, RT.7/RW.2, Slipi,

Kec. Palmerah, Kota Jakarta Barat, Daerah Khusus

Ibukota Jakarta 11410

Bill ID: 3

HP: +622153678441

Email: none

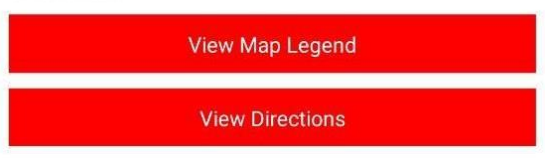

Gambar IV.21. Implementasi Halaman Data Pelanggan praNPC Halaman data pelanggan praNPC akan muncul jika pengguna aplikasi menekan marker yang terdapat di peta. Data pelanggan yang muncul adalah nama pelanggan, alamat lengkap pelanggan, Bill id pelanggan, nomor handphone pelanggan dan email pelanggan. Terdapat 2 tombol setelah informasi pelanggan, yaitu tombol View Map Legend dan View Directions. Tombol View Map Legend digunakan untuk mengubah data pelanggan yang ingin di munculkan sesuai dengan CTB yang dipilih. Tombol View Directions digunakan untuk memunculkan petunjuk arah atau directions ke lokasi pelanggan berdasarkan lokasi pengguna saat ini.

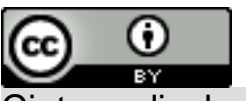


d) Implementasi Halaman Directions

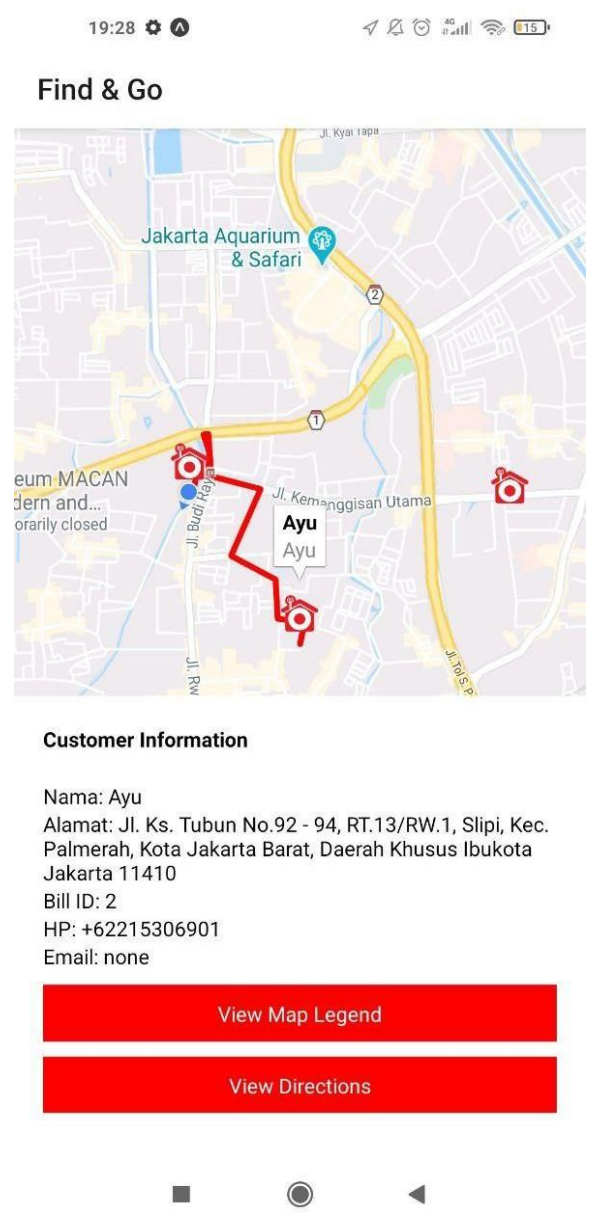

\section{Gambar IV.22. Implementasi Halaman Utama}

Gambar IV.22. Merupakan tampilan dimunculkannya garis bantu atau directions menuju lokasi pelanggan praNPC yang telah dipilih oleh pengguna.

\section{KESIMPULAN}

Hasil penelitian ini menemukan bahwa sistem informasi pelacakkan dan pemetaan visual membantu mengurangi masa waktu pencarian alamat yang tidak lengkap oleh petugas CTB PT.Telekomunikasi 
DOI: $10.52362 /$ jmijayakarta.v1i2.444

Indonesia. Sistem yang dikembangkan dapat melacak keberadaan petugas yang sedang berada di lapangan. Sistem informasi ini dapat menjadi aplikasi yang bisa di gunakan oleh teknisi jika ada gangguan internet pelanggan, terlebih lagi disinkronasi dengan maps yang ada sehingga lebih memudahkan dan efisien.

\section{REFERENSI}

[1] Suyanto. (2005). Pengantar Teknologi Informasi untuk Bisnis (Edisi Pert). Yogyakarta: Penerbit Andi.

[2] Mulyadi. 2016. Sistem Akuntansi. Jakarta. Salemba Empat.

[3] Mulyani, Sri. 2016. Sistem Informasi Manajemen. Bandung: Abdi Sistematika.

[4] Marakas GM, O'Brien JA. 2017. Pengantar Sistem Informasi. Jakarta: Salemba Empat.

[5] Jogiyanto, H.M., 2005, Analisa dan Desain Sistem Informasi: Pendekatan Terstruktur Teori dan Praktik Aplikasi Bisnis, ANDI, Yogyakarta

[6] Dr. Ir. Harijono Djojodihardjo, (1984). Pengantar Sistem Komputer. Erlangga, Bandung

[7] Jogiyanto Hartono. (1999). Analisis \& Desain Sistem Informasi : Pendekatan Terstruktur Teori dan Praktek Aplikasi Bisnis. Andi, Yogyakarta

[8] Tata Sutabri. 2012. Analisis Sistem Informasi. Andi. Yogyakarta

[9] Verdi Yasin (2012). Rekayasa Perangkat Lunak Berorientasi Objek. Jakarta : Mitra Wacana Media

[10] A.S Rosa , dan M.Shalahuddin. 2014. Rekayasa Perangkat Lunak Struktur dan Berorientasi Objek. Bandung : Informatika.

[11] Benni Triyono, Sri Purwanti, Verdi Yasin (2017) "Rekayasa Perangkat Lunak Sistem Informasi Pengiriman Dan Penerimaan Surat Atau Paket Berbasis Web", Journal of Information System, Applied, Management, Accounting and Research, e-ISSN: 2598-8719. p-ISSN: 2598-8700.Vol.1 No.1 (30 Desember 2017) p46-53 http://journal.stmikjayakarta.ac.id/index.php/jisamar/article/view/12

[12] Julinda Maya Paramudita, Verdi Yasin (2019) "Perancangan Aplikasi Sistem Penyewaan Alat Berat", Journal of Information System, Applied, Management, Accounting and Research, e-ISSN: 2598-8719. p-ISSN: $\quad 2598-8700$. Vol.3 $\quad$ No.1 $\quad(20 \quad$ Februari $\quad 2019) \quad$ p23-29 http://journal.stmikjayakarta.ac.id/index.php/jisamar/article/view/73

[13] Muryan Awaludin, Verdi Yasin (2020) "Application Of Oriented Fast And Rotated Brief (Orb) And Bruteforce Hamming In Library Opencv For Classification Of Plants”, Journal of Information System, Applied, Management, Accounting and Research, e-ISSN: 2598-8719. p-ISSN: 2598-8700.Vol.4 No.3 (14 Agustus 2020) p51-59 http://journal.stmikjayakarta.ac.id/index.php/jisamar/article/view/247

[14] Ifan Junaedi, Dimas Abdillah, Verdi Yasin (2020) "Analisis Perancangan Dan Pembangunan Aplikasi Business Intelligence Penerimaan Negara Bukan Pajak Kementerian Keuangan RI”, Journal of Information System, Applied, Management, Accounting and Research, e-ISSN: 2598-8719. pISSN: $2598-8700$. Vol.4 No.3 (14 Agustus 2020) p88-101 http://journal.stmikjayakarta.ac.id/index.php/jisamar/article/view/249 